\title{
Flexible Design as an Acquisition Opportunity
}

\author{
Diseño Flexible como Oportunidad de Adquisición
}

DOI: $10.25043 / 19098642.152$

James A. Johnson ${ }^{1}$

Ian H. Wakeling ${ }^{2}$

\begin{abstract}
Navies around the world adopt different ways of acquiring ships. Using a single large prime contractor, placing individual contracts for design, build and integration, or employing a state-owned shipyard with external support are all procurement options that we see today. 'Flexibility' in warship design is normally perceived as provision of extra empty space, weight and power, which could be filled with new equipment at some point in the future. However, this idea can be extended to describe a design that achieves true flexibility by exploiting the synergy with different acquisition strategies, adaptability allowing a choice of balanced capability and options for incremental acquisition to control cost and risk profiles. This leads to a design that will deliver a class of warships able to meet the evolving roles and threats throughout its life, whilst not introducing additional risk and cost into the programmes of any modern Navy around the world which adopts it.

To achieve this flexibility BMT have created a single base design with multiple configurations; a warship with a functional arrangement that is able to be tailored to meet the specific requirements and budget of each Navy, minimising the initial cost penalty in a programme, and maximising commonality. It also allows for modular construction techniques which not only apply to single yard construction, including small and medium shipyards, but enables blocks to be built in several shipyards.

This paper will describe the underlying considerations behind this flexibility, including incremental acquisition as a cost mitigation in procurement programmes, and the different potential partnership models between shipyard, designer and integrator in effective acquisition programmes which work to the strengths of each party.
\end{abstract}

Key words: Flexibility, Frigates, Acquisition, Strategy, Procurement, Adaptation, Capability, Cost, Risk.

\section{Resumen}

Las armadas nacionales alrededor del mundo adoptan diferentes maneras de adquirir barcos. El uso de un solo contratista principal de gran tamańo, la asignación de contratos individuales para el diseńo, la construcción y la integración, o el empleo de un astillero de propiedad estatal con apoyo externo son todas opciones de adquisición que vemos hoy en día.

La "flexibilidad" en el diseńo de buques de guerra se percibe normalmente como la provisión de espacios vacíos, peso y potencia adicionales, que podrían ser utilizados con nuevo equipo en algún momento en el futuro. Sin embargo, esta idea puede ampliarse con el fin describir un diseño que logre una verdadera flexibilidad al explotar la sinergia entre diferentes estrategias de adquisición y adaptabilidad permitiendo la posibilidad de una capacidad equilibrada y opciones para la adquisición incremental con el fin de controlar los perfiles de costos y riesgos. Esto conduce a un diseńo que ofrecerá un tipo de buques de guerra capaces de cumplir con los cambiantes roles y amenazas a lo largo de su vida útil, sin generar riesgos y costos adicionales en los programas de cualquier Marina moderna alrededor del mundo que los adopte.

Con el fin lograr esta flexibilidad, BMT ha creado un diseńo de base única con múltiples configuraciones; un buque de guerra con un arreglo funcional que puede ser adaptado para cumplir con los requisitos específicos y el presupuesto de cada Armada, minimizando la penalización del costo inicial en un programa y maximizando la homogeneidad. También permite las técnicas de construcción modular que no sólo se aplican a la construcción de astilleros únicos, incluidos los astilleros pequeños y medianos, sino que permite la construcción de bloques en varios astilleros.

Este documento describirá las consideraciones subyacentes detrás de esta flexibilidad, incluyendo la adquisición incremental como una forma de mitigar costos en los programas de adquisición y los diferentes modelos potenciales de asociación entre astillero, diseńador e integrador en programas efectivos de adquisición que trabajen enfocándose en las fortalezas de cada parte.

Palabras claves: Flexibilidad, Fragatas, Compra, Estrategia, Adquisición, Adaptación, Capacidad, Costo, Riesgo.

Date Received: February $14^{\text {tht }} 2017$ - Fecha de recepción: Febrero 14 de 2017

Date Accepted: February 28 $8^{\text {th }} 2017$ - Fecha de aceptación: Febrero 28 de 2017

${ }^{1}$ BMT Defence Services Ltd. Bath, United Kingdom. Email: jjohnson@bmtdsl.co.uk

${ }^{1}$ BMT Defence Services Ltd. Bath, United Kingdom. Email: IWakeling@bmtdsl.co.uk 


\section{Introduction}

A warship is a significant investment for any nation. The level of capability and cost inherent of the warship design chosen will depend on the roles and requirements selected by the Navy in order to support wider goals; whether this is to provide maritime security to a vulnerable coastline, influence global events in support of the nation's interests or to secure energy, food and trade routes upon which the nation is fundamentally dependent. These wider goals, and the roles of a warship which are derived from them, can sometimes be fluid and ambiguous; the threat environment and geostrategic situation undoubtedly change over time. Flexibility throughout a warship, considered from the very inception of the design, can provide a route to deliver a cost-effective procurement programme able to meet this changing capability need.

This paper outlines the synergies and common design characteristics that enable different build strategies, different customer requirements and budgets and incremental or 'spiral' acquisition to be achieved from a single base design.

'Flexibility' in warship design has typically been perceived as provision of extra empty space, weight and power in a design, which could be filled with new equipment or modules at some point in the future. However a design that achieves true flexibility is better placed to be delivered through a range of different acquisition strategies for different Navies through adaptability. This allows choice of combat system and other design features, and includes options for spiral or incremental acquisition to control cost profiles. A truly flexible warship is able to meet the evolving roles and threats throughout its life, whilst also minimising cost for this flexibility and overall ship size of the design for any one Navy. This means that no matter which acquisition strategy is chosen by each Navy, the design will adapt to deliver a capable warship without introducing additional risk and cost into the programme. A platform design which is adopted by a number of different Navies also brings wider support benefits, especially to deployed ships operating around the world as they are able to call upon a common supply chain.

\section{Considerations}

The complexity of the combat system, along with the environmental operating conditions, accommodation numbers and standards are amongst the influential drivers on the design of a warship. These areas can drive significant cost into the programme if they are not carefully considered from the start of the design process. The requirements associated with these aspects will also differ between each Navy. This means the cost of reworking a design that is originally intended for one Navy may make it unaffordable, or introduce greater risk or compromise to other Navies on the wider export market. If there is too much change required in a design the benefit of re-using the design itself is lost.

For example, a Navy may have an incumbent or indigenous supplier of combat system equipment. For a variety of reasons, including commonality with other platforms, existing training pipelines, personnel experience and economic benefits, a Navy may have a strong preference (or a requirement) to incorporate the equipment from this supplier in their future warship. Conversely, the shipyard or designer may have constrained their platform design around a single combat system due to strategic relationships, or a requirement to use a specific supplier from the Navy for which the ship was originally designed.

Fig. 1. A single base platform can be designed to suit the combat systems produced by a range of manufacturers, and a range of capabilities

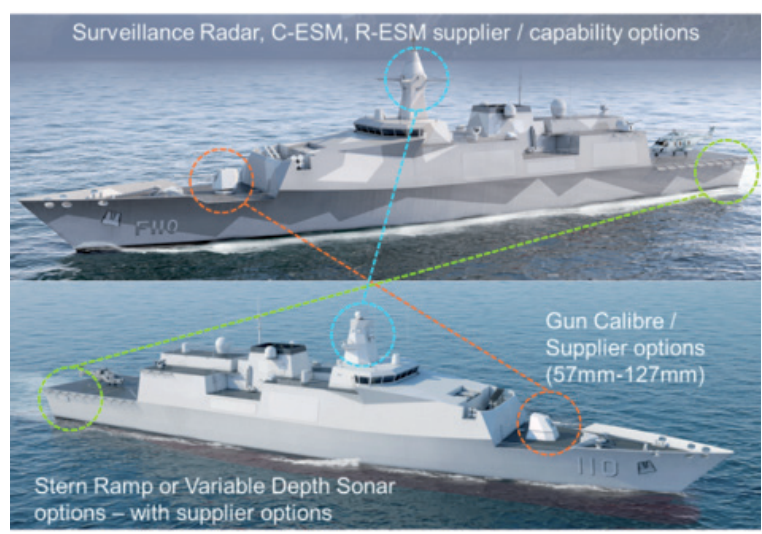


For a platform design to be attractive to a number of Navies it needs to have the flexibility to incorporate a variety of combat system equipments from different suppliers, all without increasing the risk within the design or the cost of each individual programme.

This is also the case with regard to the operating environment requirements from each Navy. For example, a ship optimised for Gulf summer operations could potentially struggle with the conditions in the north Atlantic winter, and viceversa. Again, flexibility within the platform design to accommodate these requirements can mean a single design is suited to the widest possible range of conditions, and mean that a Navy adopting this existing design will incur less additional cost and risk converting the platform to their own environmental requirements. The sizing of environmental systems to address the requirements of many different Navies also provides further benefits of through-life growth and adaptation for any one individual Navy.

A further example of this flexibility affects the manning philosophy adopted (such as conscription or lean manning) and associated accommodation standards. Within the BMT Aegir $^{\oplus}$ platform design developed for the UK as the Tide Class Fleet Tanker, the design was configured to meet Royal Fleet Auxiliary (RFA) accommodation standards. Features of the design included unmanned machinery control rooms and en-suite cabins, to meet the requirements of the RFA manning philosophy and standards. The Aegir ${ }^{\circ}$ platform design developed for the Royal Norwegian Navy and built as the HNoMS Maud was configured to accommodate both enlisted and conscripted personnel, to Norwegian standards, with other bespoke habitability features including a sauna; alongside a 40-bed hospital complex with operating theatres, isolation/intensive care wards and CT scanner. This provides a demonstration of the flexibility of a single base design to accommodate different requirements, without adding cost or risk into either the UK or Norwegian programmes in order to allow the design to conform to the other's standards.
Flexibility in a design also extends to the classification society and standards adopted. A Navy that takes a design that was created for another Navy, designed to their particular set of standards and class rules, may incur a cost, risk or schedule penalty when attempting to convert this design to suit their own policies, regulations and legal requirements. However, a platform can be designed from the start to be flexible enough to switch between the rules of different classification societies and standards to reduce this risk. This is again demonstrated by the BMT Aegir ${ }^{\circledR}$ design. Aegir ${ }^{\circ}$ was designed and built to Lloyds Register naval rules and UK Defence Standards for the UK Tide Class programme, whilst the Aegir ${ }^{\bullet}$ design for the Royal Norwegian Navy was designed and built to Det Norske Veritas (DNV) naval rules and Norwegian standards.

Fig. 2. (top) BMT Aegir ${ }^{\circledR}$ design for the UK Tide Class designed to Lloyds Register naval rules. (below) BMT Aegir ${ }^{\circledR}$ design for the Royal Norwegian Navy designed to DNV naval rules
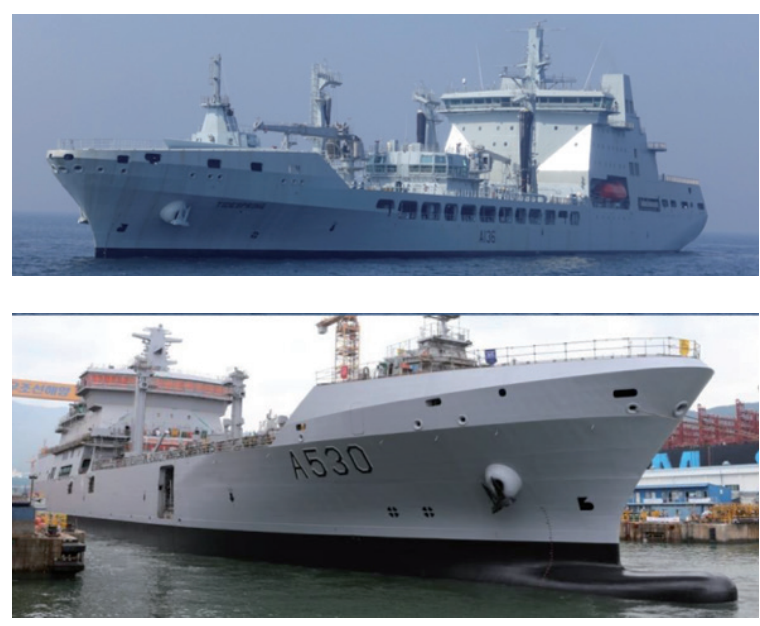

\section{Flexibility in Platform Design}

The proliferation of modular space onboard modern warships is indicative of the requirement to incorporate the latest developments in technology. From the vehicle deck within the Danish Absalon Class to the provision of dedicated space for 20-foot containers onboard modern OPV designs such as the 20 De Julio Class of 
Colombia, warships now have the ability to host equipment, such as unmanned vehicles, which are constantly being updated and upgraded. This flexible space is essential to quickly adapt to meet new roles and requirements, and to facilitate higher technology refresh rates necessary to keep pace with developments.

However, flexibility can also extend to other aspects of the platform design, bringing with it other benefits alongside spare space for enhanced capability. Through considerations around hydrodynamics, military capability, the arrangement of the platform itself and designing for potential spiral or incremental acquisition true flexibility in warship design can be achieved.

Instead of starting the design of a warship to meet a single particular cost constraint, which has very little relevance to the spectrum of Navies around the world with different industrial bases, the design is instead tailored for cost, maximising the capability against the available budget.

When BMT started the design of a Light Frigate in 2012, the platform was not designed to any one particular requirements set, or for any one particular Navy, or for construction in any one particular country. Indeed, in 2012 the Navy of BMT's home country (UK) did not have a programme for a Light Frigate, upon which costs or requirements could be based; and so it had to be designed for the full range of costs inherent in the industrial bases of the global market of Navies which require a Light Frigate. This drove a flexible 'tailoring for cost' philosophy. This is unlike the origin of Frigate designs in the past, where the ship is designed for a particular Navy, and their particular requirements set, and then subsequently marketed to other Navies. These other Navies may then have to live with certain compromises in the design made by the original Navy, which may not necessarily fit with their own requirements.

\section{Ship Sizing}

Where the design is based on a single set of defined requirements, for a single Navy, the ship is obviously sized according to the dimensions needed to fulfil these requirements. However, for a flexible design with a range of potential customers, this cannot be addressed in the same way; specific requirements cannot be detailed at the start of the process in order to drive the overall size of the ship. Without this single set of requirements there is a danger that the design may become too large and expensive for any one customer. Therefore the approach adopted by BMT was to decide on a minimum viable size of vessel, in order to manage cost, whilst using flexibility to tailor closely to differing requirements.

For the Light Frigate design, having decided upon a genuine global "blue water ocean" capable vessel (i.e. a Frigate rather than a Corvette or OPV derived hull), this defined a suitable minimum ship size based on the required and tested hydrodynamic performance. This work is described further in the paper at Reference 1.

The only firm requirements at the start of the project were based around these overall dimensions of the ship. To prevent the gradual growth of additional military requirements being added to the ship, which would result in a rapidly increasing size and price tag, the ship was not allowed to grow beyond these dimensions within this hullform in the initial stages. Balanced military capability could be provided within the ship, with the ability to provide bespoke capabilities via options, flexibility or modular upgrades. However this balanced capability was not allowed to drive up the dimensions of the ship itself, as an exploration of what could be achieved within this affordable Frigate design. Scope to enlarge this design, or 'stretch' the hullform exist; this allows the design team further flexibility to tailor to the specific requirements of each customer if required and permitted by the available budget.

\section{Military Capability}

Starting the design without one particular Navy, or one particular requirement set in mind forced the BMT design team to consider a very broad range of capabilities and potential requirements, in order to deliver balanced capability overall. 
BMT analysed the doctrine and concepts of operation of a number of nations, in order to understand the diverse picture of the range of activities that the ship may be called on to perform. Reinforced by engagement with several Navies, and support from operators from a number of countries, a list of roles and activities was drawn up. These roles were then broken down into their underlying requirements, with other important aspects such as the threat environment also considered.

Most importantly, the requirements distilled from this analysis were not specific to the doctrine of any one Navy or nation. For example, Anti-Submarine Warfare (ASW) can mean different things to a nation that is primarily required to provide a passive screen to a carrier task group, versus another nation where ASW can mean the protection of territorial waters or critical trade routes, chiefly by active means, from the covert submarine activity of a neighbour or the smuggling activities of 'narco-submarines'. Both are considered valid ASW policies by their respective Navies; however they have a disparate impact on the platform design itself.

Armed with these requirements, applicable to a range of Navies, the design team then generated the design itself with a range of capabilities tailored for cost, identifying which roles and activities were compatible with each other. Some of these roles had a number of options. For example, a number of options for the Hangar arrangement were generated, able to accommodate the range of manned helicopters operated by different Navies around the world; this was coherent with the design of the air weapons magazine arrangements to cater for the weapons carried by these different helicopters.

Other potential roles and activities of the ship that were not compatible with each other were identified as further capability options. For example, the design can either incorporate a stern ramp launched RHIB Interceptor, a Variable Depth Sonar (VDS) or a simple low cost open quarterdeck option.

Through the use of capability modelling tools and analysis over a period of several years appropriately balanced capability across surface, sub-surface and air domains was optimised for a range of budgets, with the constraint of the hull size an effective method of controlling the overall cost. This was tested against real costing of the design from external organisations including leading Combat System Integrators.

It is critical that the capability of a warship is balanced to prevent size and cost escalation. There is always a temptation within the requirements of a warship to add more capability, such as additional Vertical Launch Silos (VLS), larger mission bays, additional sensors, greater coverage for close in weapon systems (CIWS) or more medium calibre ammunition, amongst others. However these military features have to be balanced with the more mundane areas of a ship. Accommodation, HVAC, electrical generation and distribution, galley, stores, sewage treatment, data processing, chilled water and medical spaces; survivability features in areas such as shock, redundancy and a citadel; sufficient tankage for fuel, AVCAT, black/ grey/fresh water, lube oil, urea and ballast, with the associated cofferdams, required to provide an adequate range and endurance are all amongst those features that need to be located within the fine hullform and subsequent weight of a Frigate. For instance, a large mission bay within the ship is attractive from a future flexibility point of view. However, in order to maintain tolerable temperatures in very hot or cold environments the HVAC requirements for such a large open space are significant. Notwithstanding the requirement for far larger ATUs, this adds a much greater electrical load to the ship itself. Additional accommodation is required for the operators and maintainers of the equipment stowed in a large mission bay, who in turn require a greater payload of stores and fresh water, with the extra equipment in the large mission bay requiring its own support of fuel and stores. A large, open and sometimes empty space within the ship also has a fundamental impact on the buoyancy and stability (including damaged stability) of the ship itself, which has to meet both class rules and the standards of the Navy for which it is designed. It should be noted that this is particularly prevalent when increasing the number of warfighting systems onboard a warship, such as weapons and sensors, as they are placed high on the ship and have a significant impact on the top 
weight, the stability and the through-life growth margin of a Frigate; the fine hullform of which is necessary to achieve the expected end-of-life speed and manoeuvrability requirements.

From this example of a large mission bay alone it can be seen how quickly the wider requirements of a ship are driven up when the capability of the ship is not balanced. This in turn rapidly drives up the size and cost of a ship significantly. This is why BMT devoted so much effort to achieve optimised capability balances across all of these aspects discussed within the hydrodynamically tested hullform of a Light Frigate, tailored for the available budget. Flexible mission space can be provided, but it must be balanced and proportionate over the whole ship design.

This design process, known as 'Middle-Out Design' is described further in the paper at Reference 2. A key tenet of this process is the in-stride development of the design and the requirements at the same time. The fundamental understanding of the capability between the design team and the requirements team from the start has been found to produce a more coherent design.

\section{Functional Arrangement}

Flexibility does not only extend to the equipment choices and provision of military capability. Flexibility designed into a platform by way of a functional arrangement brings a number of benefits during the design and build of a warship, which can result in a lower procurement cost.

A functional, or zonal, arrangement is where systems and spaces are concentrated within particular areas or construction blocks of the ship, in order to reduce complexity where dispersal is not required for survivability. It is critical that a functional arrangement is considered from the outset of a platform design, and forms the overarching philosophy throughout the process. A high level indication of what is meant by a functional arrangement is shown in Fig. 3 below.

This means that during the design and build of the ship the shipyard, platform or combat system integrators can concentrate on a particular form of outfit within each block. This avoids attempting to fit out a main machinery space, combat system processing compartments, accommodation and main weapon systems such as missile silos in a single block for example, reducing the build complexity, and deconflicting the schedule between the different trades and outfit sub-contractors.

This also means that the interfaces between the blocks, such as cable runs and pipework, are reduced as much as possible within a warship. Each individual block can be outfitted to a higher degree prior to the blocks being brought together for final assembly, leading to a higher degree of concurrent activity during the build programme, assisting the schedule and cost $\&$ risk profiles.

Fig. 3. The functional arrangement of a warship, within 15 build blocks

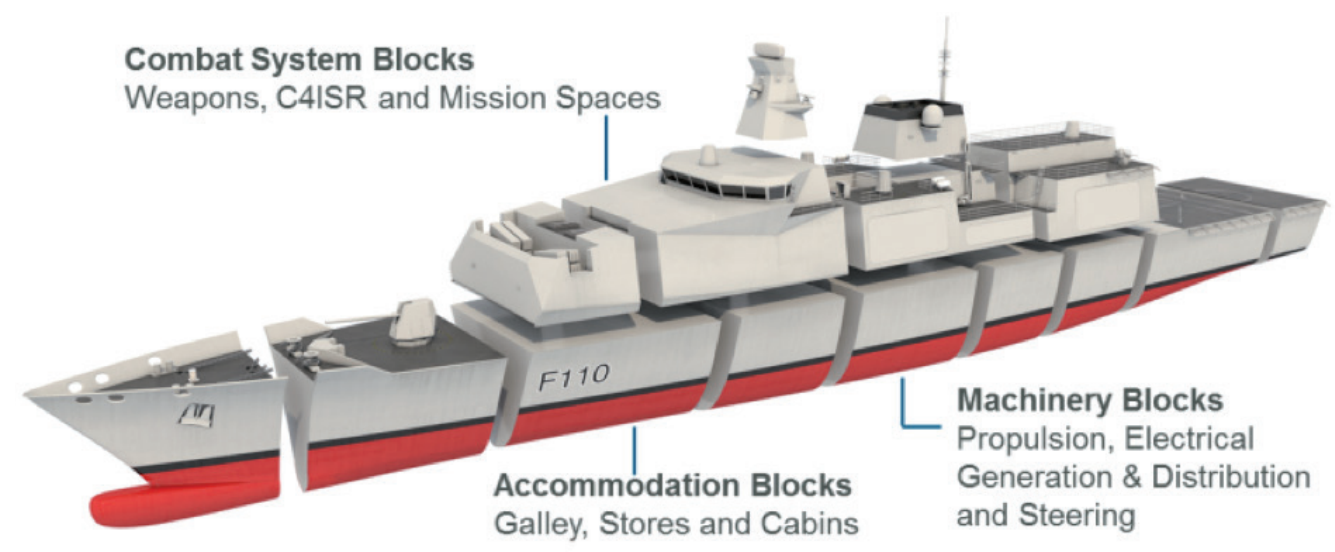


A functional arrangement also brings a higher level of flexibility to the design process, and the ability to amend a design to meet a Navy's requirements if they were to evolve during the design, due to operational reasons or a change in the threat environment. By using a functional arrangement the different sections of the ship can be amended to suit the updated requirements without impacting on the rest of the design. For example changes could be made to the accommodation blocks, whether this is to increase the number of personnel borne or to alter the accommodation standard adopted, without resulting in costly changes to other areas of the ship such as machinery or operations rooms. This reduces the whole ship design effort required, reducing the design cost within the procurement programme.

Removal routes aligned with the combat system equipment compartments mean these systems can be installed later the schedule or following build, reducing the impact of long lead items for the combat system on the build schedule. Concurrent shore-based integration and testing on the complex combat system can also take place later and occupy a longer period in the programme, further aiding the schedule and risk of the build. The combat system spaces were also designed within the BMT Light Frigate with technical design information and significant assistance from a number of different combat system equipment suppliers. This supports the ability to tailor the design to accommodate the requirements of each Navy, and tackle through-life obsolescence. This flexibility around the design of combat system equipment spaces is one feature that allows a procurement programme to follow an incremental or 'spiral' acquisition.

\section{Spiral Acquisition}

The investment that a government is willing to make in a warship programme may not entirely match the total need of a Navy, or encompass the entirety of the roles that the platform is required to perform throughout its life. In contemporary programmes this has resulted in either:

1. A cut to the number of platforms procured, a measure that itself has significant ramifications for a Navy as a whole due to force generation; or, 2. Equipment being considered 'fit to receive', where space, weight and power allowances are made for individual items of equipment in the design with some ambition to fit these at a later date; or

3. Entire capabilities lost from the programme as it becomes unaffordable.

This is most prevalent in programmes where the first of class ship is immediately required to provide the full capability identified by policy for the class upon delivery. Car and aircraft manufacturers, and even defence companies building complex military vehicles such as Main Battle Tanks, first build a significant number of prototype machines; ironing out the issues and risks within the design prior to starting a full production run for a customer. The very first warship prototype built is delivered to the customer as the first of class, and expected to provide the full capability demanded. The risks inherent in getting all of aspects of a modern warship to function together correctly, in time, in the first example of the class add significant cost to a procurement programme in the early years. This can lead to the financial pressures which result in the three courses of action described in the paragraph above.

To avoid this high initial cost and high risk for the first of class in the early years a spiral, or incremental, acquisition policy could be followed. However, for this to be successful a flexible design, including a functional arrangement, is required.

An incremental procurement is where the first of class prototype is delivered with a reduced capability against the full capability required for the class. The designer, builder and combat system integrator can then concentrate on the fundamental platform aspects such as hullform, propulsion and power generation, and certain aspects of the warfighting capability so that the vessel still meets at least the minimum level of utility when delivered. Once tests, commissioning and acceptance have been conducted on a concentrated range of aspects within this first of class, the lessons for these aspects will have been fed back into the later ships of the class. 
Subsequent ships can then concentrate on delivering the higher end capability required, without the risk and cost of having to prove the entire platform at once. It is important however that the base platform for these later ships is still the same as the first of class. This initial prototype ship of a class cannot be designed to a low cost for affordability, with subsequent ships fundamentally re-designed to incorporate higher levels of capability as all benefit of commonality and the risk-reduction effort is lost, and the overall programme will be far more expensive.

A good example of this incremental strategy is that adopted during the Danish Iver Huitfeldt Class Frigate acquisition, described later within this paper. In this Danish example the first of class prototype was later refitted with the additional capability to bring her up to the full class requirement, and only entered service at full capability after all other ships in the class were delivered.

This incremental acquisition, together with the functional arrangement, also raises other opportunities for the capability that the Navy can acquire. As the design itself has the flexibility and space to be reconfigured without incurring significant costs, additional capability can be added to later ships of a class if the threat environment or roles change during the build programme, or more funding becomes available.

For example, the stern sections could be changed to a Variable Depth Sonar option, or the number of cells in the Vertical Launch Silo (VLS) could be increased, or swapped out for a different type of silo. These capability upgrades on later ships are a more cost effective method of acquiring this capability, reducing the risk overall by spreading out the design, build, test and acceptance risk for different aspects of the programme over time. The functional arrangement means that only certain individual blocks require this re-design effort, which would not affect the overall platform, reducing the associated cost and maximising commonality. If a Navy wished to procure an initial batch of ASW specialised Frigates, followed by a second batch of AAW specialised Frigates, this functional arrangement means that the commonality of the base platform is also accentuated between the two batches, contributing to a lower through-life cost.

This concept can also be extended to incorporate the latest technologies and equipment, to mitigate the risk of obsolescence. For instance, the internal layouts of individual main machinery blocks could be re-designed with energy storage solutions when the technology matures, used for both electric propulsion systems and Directed Energy Weapons or Railguns. Hangar and flight facilities could be adapted to new helicopters or unmanned vehicles as the existing solutions go out of service. Finally combat system equipment, such as multifunction radars, communications or anti-ship missiles could be changed for future solutions that are relevant against the evolving threat, all with minimal impact on other parts of the ship outside the functional block in question; retaining the maximum level of commonality across the fleet

During the design of the Light Frigate, BMT found that this form of spiral acquisition and flexibility has to be considered very carefully, which has informed the latest variant of the design. This is

Fig. 4. Example of VLS options within a Light Frigate design, which could be adopted over a class of ships to provide greater capability once the initial risks are resolved or mitigated

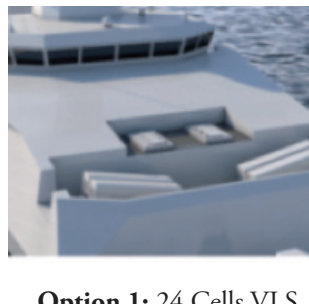

Option 1: 24 Cells VLS

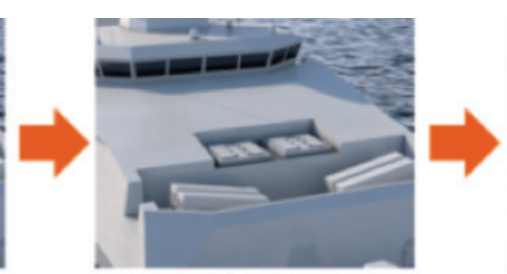

Option 2: 48 Cells VLS

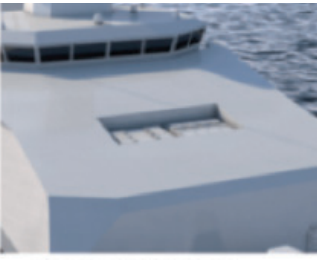

Option 3: 24 Cells VLS, with 8 cell Strike Lenght VLS 
to avoid adding too much extra space and power margin in the initial design, bringing in unwanted additional cost to the first of class. Overall, this is a drive to consider adaptability, and the tailoring of a warship for cost, at a whole ship level.

Fig. 5. Spiral, or incremental acquisition. This can lead to the introduction of new technology or roles in later ships of a class, or potential to adapt to an evolving threat environment, in a programme with a smoother cost and risk profile

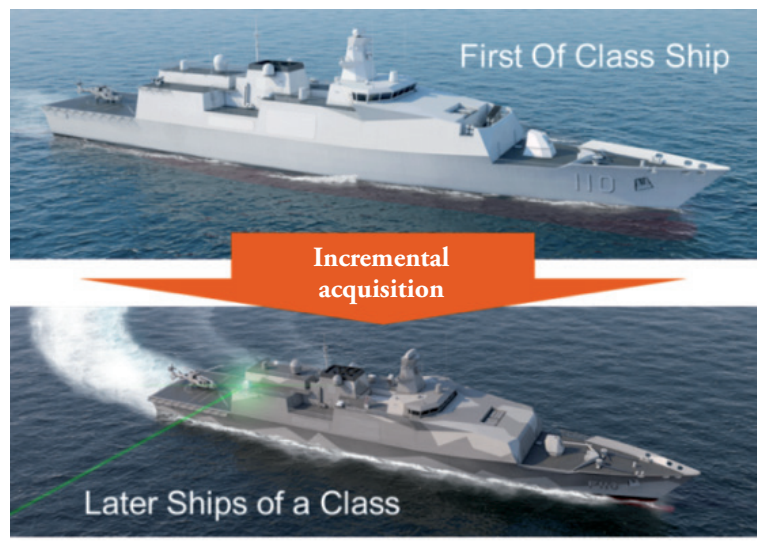

The effect of this spiral development could also be seen on the learning curve experienced during the build programme over a class of ships. Fig. 6 below shows the learning curve that was experienced during the Royal Navy Leander Class Frigates programme built in the UK. The reduction in cost for each platform during that programme can be seen, due to the learning experienced by the shipbuilder and therefore the manhours saved, once the first few ships of the class (the prototypes) were completed. The second line shown is an example of the effect a spiral or incremental development could have on a programme. The initial costs of the programme are lower due to the installation and de-risking activity on a more concentrated range of platform aspects, which is balanced by inserting this capability back into the early ships later in the programme once the de-risking activity has taken place on the initial vessels. This also leads to a smoother cost profile over the course of the entire programme, especially in the difficult early years.

Overall however, despite delivering these benefits discussed, including enabling a variety of different capability configurations within a single base design, the BMT Light Frigate is actually a straightforward design. The propulsion and power generation system is proven and already at sea, and

Fig. 6. Learning Curve Comparison

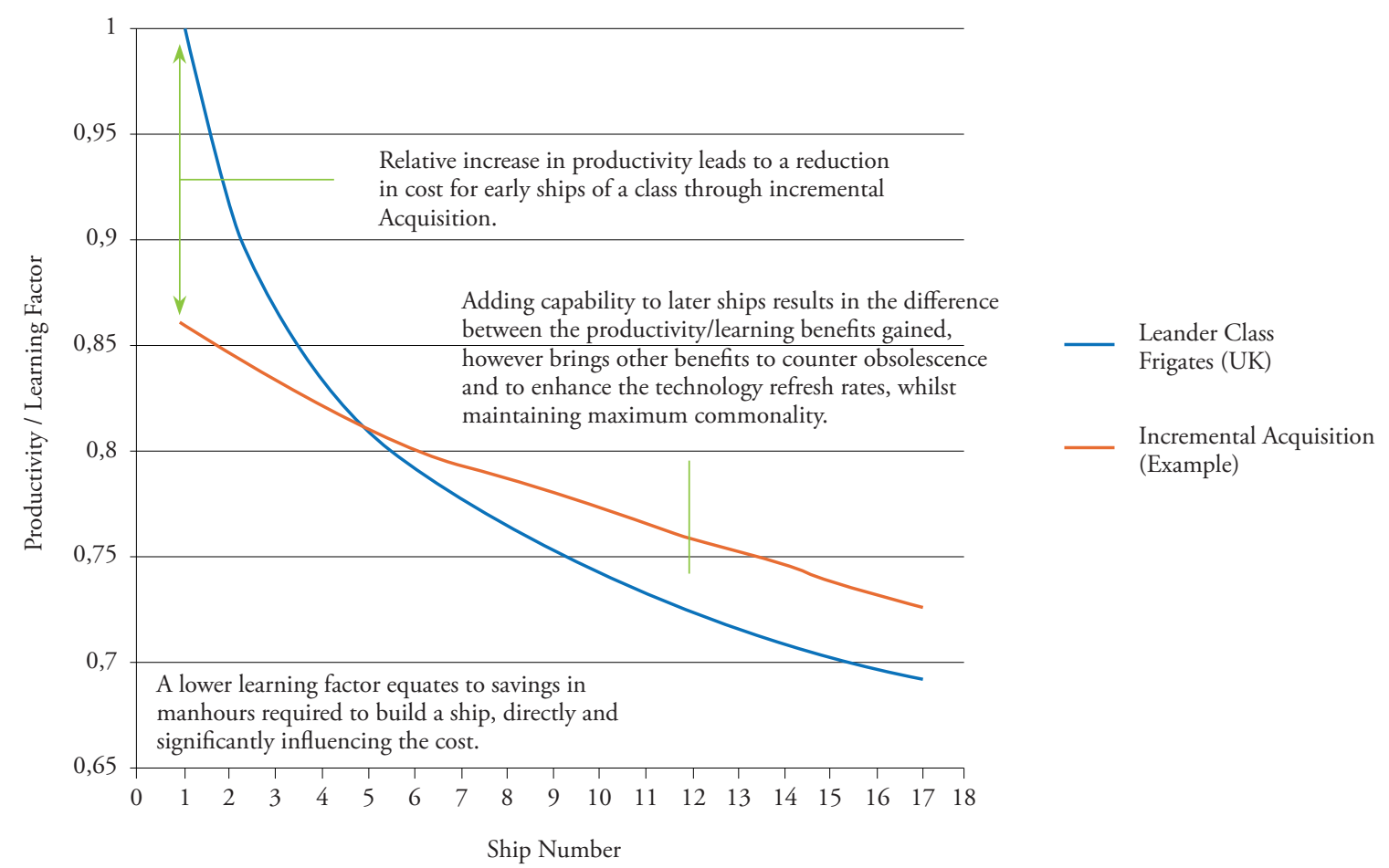


a great deal of intelligent effort over several years has been put into the arrangement and layout to meet naval class rules and standards, and to provide survivability. Significant effort has been devoted by BMT, along with platform system integrators and combat system integrators, to develop a warship which can meet the requirements of a modern Navy but is not complicated for a shipbuilder to construct. This simplifies the build and minimises the cost and risk within the base design.

\section{Flexibility in Acquisition Strategy}

The flexibility to tailor the design to meet the operational needs and budgets of a range of Navies also opens up applicability to a variety of acquisition strategies; in a way that a more constrained design developed for a single Navy within a conventional acquisition strategy may not without bringing additional unwanted change, risk and cost.

The acquisition strategy for a new warship can take several different paths. The strategy selected will depend on the policy of the government, the available infrastructure within the country and the needs and budget of their Navy, amongst other factors. There is also a rapidly increasing demand from a number of countries for warships to be built bespoke to their own requirements, and built within their own country, rather than follow the previous strategy of buying second-hand ships. A Navy may also wish to specify individual systems or equipment produced by manufacturers in their own country. This is where a flexible design, and a functional arrangement, is required so as not to introduce a high level of re-design work to accommodate these new system choices, which would add risk and cost into the programme and make the design itself unattractive or unaffordable. For reference, Lamb (2013) (Reference 3) outlined a number of acquisition strategies that could be taken, and Tascon (2015) (Reference 4) further analysed these different potential approaches.

One acquisition strategy to highlight is that used to acquire the Iver Huitfeldt Class Frigate. The acquisition of the Iver Huitfeldt Class by the Danish Defence and Logistics Organisation (DALO) used a model that had strong parallels with the commercial procurement of ships by companies such as Maersk. This also provides a good example of a flexible design, based on the earlier Absalon Class, and was designed by the Royal Danish Navy and the Odense Steel Shipyard working in close co-operation. The platform, combat system and integration of the Iver Huitfeldt Class were split, with the DALO organisation itself effectively taking responsibility as the prime over all these elements. All of the blocks for the three ships of the class were constructed by Baltija Shipyard (Lithuania) and Loksa Shipyard (Estonia), before final assembly in Odense Shipyard (Denmark), taking advantage of the lower overheads presented by these commercial shipyards.

Fig. 7. The three Frigates of the Royal Danish Navy Iver Huitfeldt Class

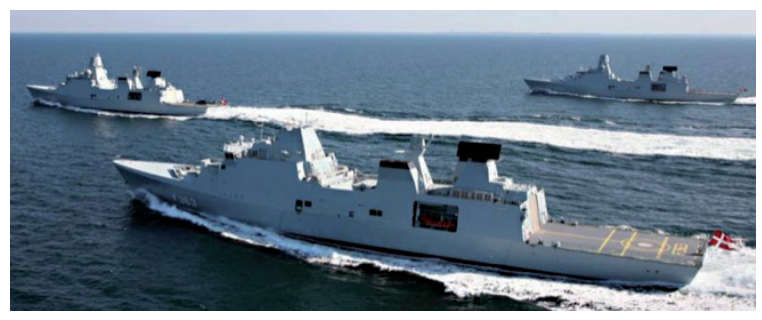

Once the platforms themselves were complete, the installation of the military equipment and testing took place. Procurement of this combat system equipment was also undertaken ('primed') by the DALO itself. The incremental, or spiral, acquisition and testing within the programme is demonstrated in the image of the Iver Huitfeldt Class shown in Fig. 7. The ship at sea in the foreground is not fitted with air/surface search radar (Thales APAR) and satcomms on the main mast, and with several weapon systems yet to be installed.

A high level diagram of the project plan for the Iver Huitfeldt class is included in Fig. 8 below, extracted from a briefing produced by the Royal Danish Navy (Reference 5). This shows the derisking activity that took place on the first of class ship, where the installation of the combat system was split. This resulted in this first of class 'prototype' vessel only entering service at full capability after all other platforms in the class were 
Fig. 8. Danish Frigate Programme Main Plan (extract from Reference 5)

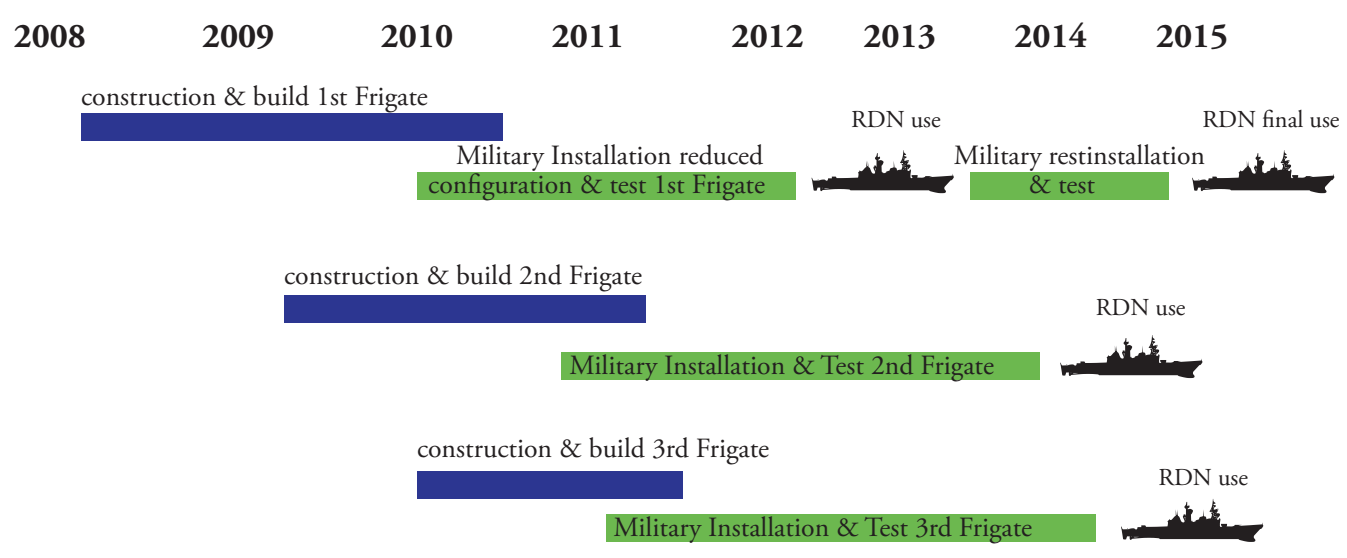

introduced. In addition, the installation of SM-2 missiles across the entire class, to enable the full capability requirement to be met, was conducted after the ships had entered service; shorter range air defence Evolved Sea Sparrow Missiles (ESSM) were used initially as an interim capability. This demonstrates a form of spiral or incremental acquisition as described earlier within this paper.

It is claimed that this split procurement model, where platform and combat system were procured, built, integrated and tested separately and incrementally saved around USD 65 million per vessel overall (Reference 6), with the allocation of risk within the programme a contributory factor. This resulted in a low procurement cost of these vessels, when compared to contemporary Frigate programmes. A breakdown of the cost for these Frigates has also been published (Reference 6), showing almost a 50/50 split in costs between the platform and combat system elements. However, it is important to note that for this type of acquisition strategy to be successful it is vital that the platform design itself is flexible enough to allow the selection and fit of the combat system once the ship itself has been built. This was aided in this case by the Danish Stanflex modular system, overall supporting the separate and parallel construction of blocks.

\section{Acquisition Strategy - Alliance Approach}

Not all governments will have the capability and capacity to undertake the prime integration role as taken by the DALO in the Danish example described above. However, many of the benefits of the approach can be delivered through a strategy based on the engagement of an alliance. The Navy or procurement body can work as closely with alliance members as they wish, depending on their capabilities and desire to learn through participation in the project, tailoring the levels of technology transfer to suit all parties.

The flexible alliance incorporates a Shipbuilder, a Platform Designer, a Combat System Integrator (CSI) and a Platform System Integrator (PSI). The level of involvement each party plays depends on the nature of the acquisition strategy, and some roles may be fulfilled by the same company. The focus of effort will change between these parties as the programme proceeds.

The Shipbuilder: The shipbuilder can be abroad or in the customer's own country. In cases where the customer wishes to build the warship in their own country, but lacks experience, a shipyard consultant may be part of the alliance providing expertise and support to the local shipbuilder. This consultant party may be a shipyard itself but the advice could come from suitably experienced consultants.

More than one build facility may be used with blocks being built in different locations and integrated together by the lead Shipbuilder. A design specifically developed to support such an approach is needed to avoid significant additional 
costs being incurred. This allows the progressive development of industrial capabilities, and can speed up delivery.

In the early stages of the project the Shipbuilder's role will be in providing comment on the developing design to ensure that construction issues are addressed. They will also commence engagement with potential equipment suppliers, obtaining prices and data (including space, weight and power requirements) to support design development and trade-off decisions. This will also support planning for construction. If applicable, any requirements for development of facilities will also be identified. As the project proceeds the Shipbuilder will be increasingly involved in planning and procurement of long lead items. The shipbuilder will again be supported by the shipyard consultant as needed.

Depending on Shipbuilder capability they may also become progressively involved in developing the detailed and production design, under supervision of the Designer, to ensure that the original design intent is maintained.

\section{The Designer}

The Designer will take the lead in the early stages, working with the customer to explore options to focus the design on a reasonable compromise that best meets the balanced operational requirements and budgetary constraints. Working from a flexible baseline design as discussed earlier in this paper prevents high levels of re-work, significantly speeding up this process and reducing cost. Whilst input will be required from the Combat System Integrator, the level of detail needed is kept low allowing work to continue on development of the combat system design itself within defined boundaries, without causing change to the rest of the overall design. Development of the design can also recognise customer requirements for variations between vessels in the same class, either to meet a fleet capability mix requirement or to facilitate future upgrades.

As the design matures, detailed design, drawing work and production outputs may be undertaken by the shipyard or other in-country contractors under the supervision of the designer, as required by the industrial policy.

\section{The Combat System Integrator}

The Combat System Integrator is responsible for the delivery of key capabilities of a warship. This includes design, equipment procurement, system integration, testing and demonstration of the combat system. They may also undertake installation, as demonstrated by Saab with the Royal Thai Navy Frigate currently under construction by DSME, or by Thales integrating the combat system within Project Khareef for the Royal Navy of Oman.

Regardless of whether all equipment chosen is already in-service, the integration of the equipment with each other and the command system requires significant effort. It is good practice to integrate systems ashore before installing on the ship, simplifying the physical work and deconflicting interference between ship construction and combat system installation, integration and testing. The down side of this is that they system may not be ready for installation as early as the build schedule would permit. The flexible design with a functional arrangement, described above, allows ship construction and potentially testing to be completed before the Combat System Integrator takes responsibility for installation and testing of the Combat System, working with the shipbuilder or in a separate naval dockyard.

\section{The Platform System Integrator}

Depending on the complexity of the propulsion and power generation systems, and the sophistication of the control systems required for these and the auxiliary systems, there may be a need for a Platform System Integrator to take responsibility for the design and integration these systems. Including the Platform Management System and the power and propulsion equipment, this is similar to the Combat System Integrator with the Combat System. Again, the flexible design with a functional arrangement allows the Platform System Integrator to develop their aspects of the design, within defined boundaries, with minimal 
risk that design development will cause changes and disruption to development of the rest of the overall platform design.

For requirements at the more straightforward end of the spectrum this role will normally be fulfilled by the Designer with procurement by the Shipbuilder.

\section{Summary}

Flexibility in warships has a greater meaning than the provision of empty space for modular upgrade at some point in the future. True flexibility throughout is a critical feature of warship designs which can provide a balanced capability, tailored for cost, and able to mitigate the risks of obsolescence and the changing threat environment. With the ability to evolve into new roles as the global situation develops, this flexibility can also maximise commonality within the fleet, and with the fleets of other nations that tailor to the same design, delivering through-life cost benefits.

Flexibility in warship design has to be considered carefully from the start of the design process, in a way that does not bring extra cost into the platform design itself; so that a Navy is not penalised by paying for additional features, or a larger warship than they require.

Through the design of a Light Frigate over the past few years, BMT have found that a functional arrangement is a way of managing this flexibility. This functional arrangement can simplify the build of a ship, by limiting the interactions between the blocks, leading to a greater degree of pre-outfitting before final assembly. This functional, or zonal, arrangement also serves as a method of keeping control of costs during the design phase if the Navy adds or changes requirements, and provides a cost effective method of adopting new technologies as they develop.

Spiral development over a class of warships, through the use of a cost-effective functional arrangement, can ease affordability versus capability conflicts. Delivering full capability over a number of ships in the class can reduce the risk inherent within the first of class prototype vessel, and reduce the impact of obsolescence. This is especially the case if the class is to be built over a long time period, where advancements in technology mean that if the last ship in a class were to be built to the same specification as the first it would suffer significant shortfalls against the evolved threat and intended roles.

A warship designed in this way supports adaptation for different Navies no matter what acquisition strategy is chosen. In particular it facilitates the adoption of an Alliance based acquisition strategy, which allows flexibility in customer involvement and home nation industry involvement and learning. Shipbuilder, Designer, Combat System Integrator and Platform System Integrator can work in parallel with clear interfaces with reduced risk of re-work and options for spiral development. The combination of a truly flexible design, readily adaptable to meet a range of balanced requirements and tailored for cost, with an arrangement that minimises the cost impact of change, and a flexible alliance engaging the optimum mix of government and contractors offers true flexibility in acquisition.

\section{References}

1. A. KIMBER, Exploring Flexibility and Design Families for Future Warships, Pacific 2013.

2. A. KIMBER, B. THORNE, How to Square the Circle for the Next Generation of Patrol Ship Designs, RINA Warships June 2013.

3. T. LAMB, A Frigate in 10 years - Challenges and Opportunities, Ship Science \& Technology Vol 7 (13), 2013.

4. O.D. TASCON, M.E. SANJUAN, A Tradeoff Space for the Evaluation of Warship Procurement Strategies, RINA Warships 2015.

5. Cdr S.G PER HESSELBERG, The Danish Frigate Program, USN Visit, [online], available at http://www.ndia.org/Divisions/Divisions/ International/Documents/U.S.-Denmark $\% 20$ 
Defense \% 20 Industry\%20 Seminar / Danish\%20frigate $\% 20$ program $\% 20$ visit $\% 20$ USN\%20May\%202014.pdf May 2014.

6. OMT, Danish Frigate Program, [online], available at https://www.aspistrategist.org.au/ wp-content/uploads/2014/11/OMT-DanshFrigate-Programme-April-2014.pdf April 2014. 